\title{
Design and synthesis of multi-target directed 1,2,3-triazole-dimethylaminoacrylo yl-chromenone derivatives with potential use in Alzheimer's disease
}

Hajar Karimi Askarani ${ }^{1}$, Aida Iraji ${ }^{2}$, Arezoo Rastegari ${ }^{3}$, Syed Nasir Abbas Bukhari ${ }^{4}$, Omidreza Firuzi², Tahmineh Akbarzadeh ${ }^{1,3}$ and Mina Saeedi ${ }^{3,5^{*}}$

\begin{abstract}
To discover multifunctional agents for the treatment of Alzheimer's disease (AD), a new series of 1,2,3-triazolechromenone derivatives were designed and synthesized based on the multi target-directed ligands approach. The in vitro biological activities included acetylcholinesterase (AChE) and butyrylcholinesterase (BuChE) inhibition as well as anti-A $\beta$ aggregation, neuroprotective effects, and metal-chelating properties. The results indicated a highly selective BuChE inhibitory activity with an $I C_{50}$ value of $21.71 \mu \mathrm{M}$ for compound $\mathbf{1 0 h}$ as the most potent compound. Besides, compound $\mathbf{1 0 h}$ could inhibit self-induced $A \beta_{1-42}$ aggregation and $A C h E-i n d u c e d ~ A \beta$ aggregation with $32.6 \%$ and 29.4\% inhibition values, respectively. The Lineweaver-Burk plot and molecular modeling study showed that compound $\mathbf{1 0 h}$ targeted both the catalytic active site (CAS) and peripheral anionic site (PAS) of BuChE. It should be noted that compound $\mathbf{1 0 h}$ was able to chelate biometals. Thus, the designed scaffold could be considered as multifunctional agents in AD drug discovery developments.
\end{abstract}

Keywords: $A \beta$ aggregation, Biometal chelator, BuChE inhibitor, Chromenones, Neuroprotectivity, 1,2,3-triazole

\section{Introduction}

Dementia is one of the noteworthy problems in the public health management as over $80 \%$ of dementia cases are suffering from Alzheimer's disease (AD). Currently, available therapies provide temporary symptomatic relief but do not target the distractive neuropathology. Therefore, a new treatment to delay or halt disease progression has remained as an urgent medical need.

The pathophysiological processes in $\mathrm{AD}$ have still remained unclear to this day. However, alongside its complexity, several neurodegenerative processes could

\footnotetext{
*Correspondence: m-saeedi@tums.ac.ir

${ }^{3}$ Persian Medicine and Pharmacy Research Center, Tehran University of Medical Sciences, Tehran, Iran

Full list of author information is available at the end of the article
}

be identified which include (I) aggregation of insoluble amyloid beta $(A \beta)$ plaques mostly trigger from sequential cleavage of amyloid precursor protein (APP) by the aspartyl protease $\beta$-site APP cleaving enzyme-1 (BACE1) and $\gamma$-secretase, (II) neurofibrillary tangles (NFTs) form through hyperphosphorylation of tau proteins, (III) biometals dysfunction, and (IV) oxidative stress which in return results in synapse loss and death of neuronal cells in the brain [1]. Also, different hallmarks have been recognized including the loss of cholinergic neurons, reduction of the neurotransmitter acetylcholine (ACh), and increased expression of inflammatory mediators [2-4].

Based on the approved theory for $\mathrm{AD}$, the loss of cholinergic neurons causes reduction of $\mathrm{ACh}$. As a result, inhibition of the acetylcholinesterase (AChE) raises the level of $\mathrm{ACh}$ and improves cognitive performance 
at the early stage of $\mathrm{AD}$. The critical point is that the $\mathrm{AChE}$ level decreases with the progression of $\mathrm{AD}$, subsequently, AChE inhibition seems to be ineffective during the progression of $\mathrm{AD}[5,6]$. Interestingly, the level of butyrylcholinesterase $(\mathrm{BuChE})$ remains unchanged or even increases at the late stage of disease [7]. BuChE can hydrolyze $\mathrm{ACh}$ and thereby, compensates the reduction of AChE activity [8]. A recent experiment with AChE knockout mice supported this hypothesis [9]. Results from further studies were in accordance with the role of $\mathrm{BuChE}$ in $\mathrm{AD}$ brains and showed a positive correlation between selective BuChE inhibition and improved cognitive performance and memory $[10,11]$.

BuChE has $65 \%$ amino acid sequence similarity to AChE along with mostly similar functions [12-14]. AChE and BuChE active sites have five subsites, including catalytic active site (CAS), peripheral anionic site (PAS), acyl binding pocket, oxyanion hole, and anionic subsite [15]. One of the structural differences between AChE and $\mathrm{BuChE}$ can be associated with acyl pocket size. More specifically, smaller residue such as Leu286 and Val288 of $\mathrm{BuChE}$ acyl pocket provide a larger site in BuChE while aromatic and bulky Phe 295 and Phe 297 residues of AChE acyl pocket afford smaller space in AChE. Mentioned structural differences contribute to the design of selective inhibitors $[5,8,16]$.

Moreover, produced $A \beta$ peptides can aggregate into $A \beta$ plaques which initiate pathogenic cascade leading to neuronal loss and dementia. Inhibition of the accumulation of $A \beta$ peptide in the brain could be another therapeutic strategy against the development of AD [2]. The metal chelatory potential of compounds has also been demonstrated to exert beneficial effects via decreasing plaque aggregation $[17,18]$.

\section{Results and discussion Design}

Because of the multifactorial and sporadic nature of AD, the modern approach "multi-target-one disease" could be efficient to develop effective agents to act simultaneously at different targets. Selective BuChE inhibitors could be a promising target for the treatment of $\mathrm{AD}$ at the moderate and advanced stages of the disease [19]. Closer looks at X-ray crystallography of $\mathrm{BuChE}$ depicted that it usually tolerates bigger scaffolds than $\mathrm{AChE}$ as the active site of BuChE is approximately $200 \AA$ larger than AChE. Analysis of the potent $\mathrm{BuChE}$ inhibitors revealed that the $\mathrm{N}$-containing ring could be effective for the interactions with ChE active site (Fig. 1). Molecular docking evaluation of compound $\mathbf{A}$ depicted that coumarin moiety interacted with Trp231 and Phe329 residues of CAS pocket and benzyl pyridinium moiety interacted with Trp82 of BuChE PAS pocket [20]. According to the interaction mode of compound $\mathbf{B}$, it can be understood that 1,2,3-triazole-aryl moiety led to the formation of hydrophobic interactions with amino acids of PAS and chromenone ring oriented towards CAS pocket [21]. In the case of compound $\mathbf{C}$, diphenyl fit into the BuChE CAS pocket while the benzyl triazine pendant group showed $\mathrm{H}$-bond interaction with the PAS of BuChE [22, 23]. As appeared in compounds $\mathbf{B}$ and $\mathbf{C}$, increasing bulkiness and length of drug candidate could increase the selectivity of BuChE over AChE. As can be seen in compound $\mathbf{D}$, the presence of relatively spacious moieties can affect the interaction of the designed compounds with that amino acid within the active site of BuChE. As a result, introducing a dimethylamino propenone entity into our system increased the length and volume of the designed scaffold which might be a good strategy to increase selectivity towards BuChE [24]. Besides, this part could also exhibit metal-chelating potential [25].

In the case of anti-A $\beta$ plaques aggregation, it is important to keep the potential moiety in the structure to inhibit the aggregation of the toxic peptide.

Coumarin structures as active natural compounds may simultaneously possess anti-oxidative $[2,26]$, neuroprotective [27] anti-ChE [20] and anti-A $\beta$ aggregative properties $[28,29]$. Coumarins pharmacophore owing to the presence of polar elements in the structure (Fig. 1, compound $\mathbf{E}$ and $\mathbf{F}$ ) might help to inhibit amyloid fibril formation through the interaction with the polar surface of $\mathrm{A} \beta$ [30-32]. Hence, coumarins could serve as a potent framework for the prevention of $A \beta_{1-42}$ aggregation [28]. In addition to the inhibition of BuChE and $A \beta$ plaques aggregation, an inhibitor that can tackle toxicity of $A \beta$ peptide, ROS and RNS could be effective for a longer period of AD progression. Recently, iminochromene ring was characterized as a potent neuroprotective agent. In this project, the iminochromene group of compound $\mathbf{G}$ was bioisosterically replaced with chromenone moiety to evaluate the possible neuroprotectivity [33]. Hence, in the present work, a molecular hybridization and bioisosteric replacement approaches were used to design and synthesize multi-target agents with anti-BuChE, anti- $\mathrm{A} \beta$ aggregation, neuroprotective, and metal chelating properties.

\section{Synthesis}

of 1,2,3-triazole-dimethylaminoacryloyl-chromenones Synthesis of the tilted compounds 10a-m was conducted according to the steps shown in Scheme 1. Desired starting material, 2-hydroxy-4-(prop-2yn-1-yloxy)benzaldehyde (3) was exactly prepared according to the literature [34]. Then, the reaction of compound 3 and excess amounts of ethyl acetoacetate (4) in ethanol at room temperature overnight afforded 

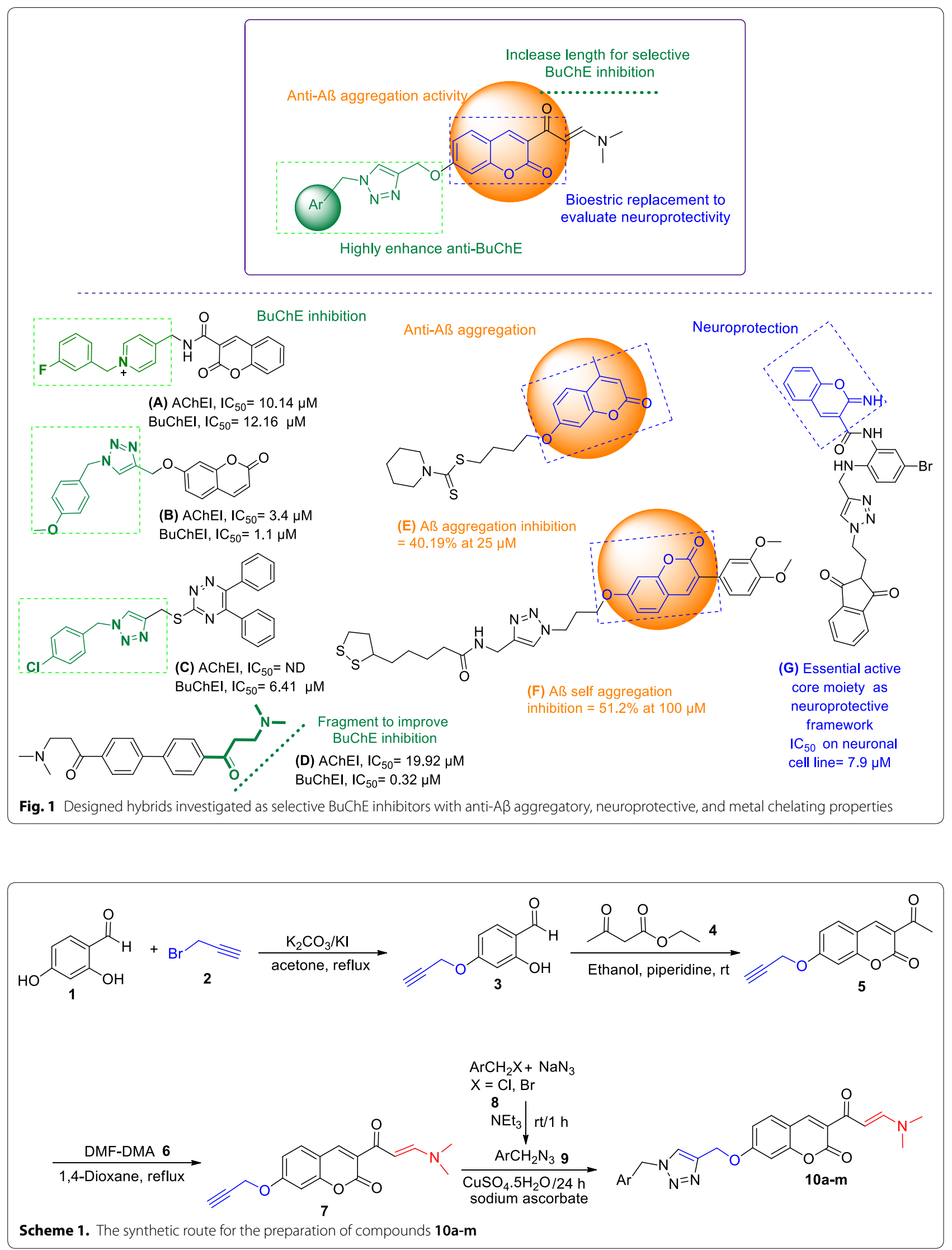
3-acetyl-7-(prop-2-yn-1-yloxy)-2H-chromen-2-one (5). Reaction of compound 5 and dimethylformamiddimethylacetal (DMA-DMF) in 1,4-dioxane under reflux conditions for $6 \mathrm{~h}$ led to the formation of $(E)-3$ (3-(dimethylamino)acryloyl)-7-(prop-2-yn-1-yloxy)$2 \mathrm{H}$-chromen-2-one (7). Finally, click reaction [35] of compound 7 and in situ prepared azides 9 in the presence of triethylamine and $\mathrm{CuSO}_{4} .5 \mathrm{H}_{2} \mathrm{O}$ in the mixture of water and tert-butyl alcohol at room temperature for $24 \mathrm{~h}$ gave the corresponding products $10 \mathbf{a}-\mathbf{m}$.

\section{AChE and BuChE inhibitory activity}

In vitro anti-AChE and anti-BuChE activity of synthesized compounds, 10a-m were performed based on the modified Ellman's method [36] comparing with donepezil as the reference drug. Compounds were initially screened in vitro against $\mathrm{AChE}$, and none of them exhibited inhibitory properties against the AChE enzyme. Interestingly, half of the 1,2,3-triazole- chromenone derivatives showed remarkable and selective inhibitory potency towards BuChE, which exerted a more prominent role at later stages of the disease [37].

As can be seen in Table 1, the BuChEI activity directly depended on the electronic property of substituents and their positions on the benzyl moiety connected to 1,2,3-triazole ring. Results showed that compound $\mathbf{1 0 h}$ possessing 3,4-diF on the aryl ring induced the best BuChE inhibitory activity $\left(\mathrm{IC}_{50}=21.71 \mu \mathrm{M}\right)$; however, the elimination of 3-F completely changed the activity in such a manner that compound $\mathbf{1 0 g}$ showed no inhibitory activity. meta-Fluorinated derivative $\mathbf{1 0 f}$ was found to be a moderate inhibitor as the calculated $\mathrm{IC}_{50}$ value was $59.58 \mu \mathrm{M}$ and para-fluorinated derivative $\mathbf{1 0 g}$ showed no inhibitory activity towards BuChE $\left(\mathrm{IC}_{50}>100 \mu \mathrm{M}\right)$.

Considering the inhibitory activity of other halogenated derivatives $\mathbf{1 0} \mathbf{i}-\mathbf{m}$ depicted that chlorinated compounds $10 \mathbf{i}$ and $10 \mathbf{j}$ showed no inhibitory activity $\left(\mathrm{IC}_{50}>100 \mu \mathrm{M}\right)$. In the case of brominated derivatives 10k-m, compounds $10 \mathbf{l}$ possessing $\mathrm{Br}$ at 3-position of aryl ring showed moderate activity with $\mathrm{IC}_{50}$ value of $65.96 \mu \mathrm{M}$.

In the case of the electron-donating substituent ( $\mathrm{Me}$ and $\mathrm{OMe}$ ), relatively good results were obtained. The presence of methyl group at 2-position of aryl moiety (compound 10b) led to relatively good anti-BuChE activity $\left(\mathrm{IC}_{50}=35.73 \mu \mathrm{M}\right)$; however, the presence of the same group at 4-position of compound 10c completely diminished inhibitory activity $\left(\mathrm{IC}_{50}>100 \mu \mathrm{M}\right)$. Another point comes back to the derivative 10d containing OMe group at 3-position on the benzyl ring which led to higher activity $\left(\mathrm{IC}_{50}=23.44 \mu \mathrm{M}\right)$. Finally, the absence of substituent on the aryl ring (compound 10a) also depicted good BuChE inhibitory activity $\left(\mathrm{IC}_{50}=34.41 \mu \mathrm{M}\right)$.
Table 1 Anti-cholinesterase activity of 1,2,3-triazole-<smiles>CN(C)/C=C/C(=O)c1cc2ccc(OCc3cn(CC4CCCCC4)nn3)cc2oc1=O</smiles>

dimethylaminoacryloyl-chromenone 10a-m

\begin{tabular}{|c|c|c|c|c|}
\hline Entry & $\mathrm{Ar}$ & Product 10 & AChEI IC $_{50}(\mu \mathrm{M})$ & BuChEI IC $50(\mu \mathrm{M})$ \\
\hline 1 & $\mathrm{C}_{6} \mathrm{H}_{5}$ & $10 a$ & $>100$ & $34.41 \pm 0.23$ \\
\hline 2 & 2-Me- $\mathrm{C}_{6} \mathrm{H}_{4}$ & $10 \mathrm{~b}$ & $>100$ & $35.73 \pm 0.21$ \\
\hline 3 & 4-Me- $\mathrm{C}_{6} \mathrm{H}_{4}$ & $10 c$ & $>100$ & $>100$ \\
\hline 4 & $3-\mathrm{MeO}-\mathrm{C}_{6} \mathrm{H}_{4}$ & $10 \mathrm{~d}$ & $>100$ & $23.44 \pm 0.07$ \\
\hline 5 & $2-\mathrm{F}-\mathrm{C}_{6} \mathrm{H}_{4}$ & $10 \mathrm{e}$ & $>100$ & $>100$ \\
\hline 6 & $3-\mathrm{F}-\mathrm{C}_{6} \mathrm{H}_{4}$ & $10 f$ & $>100$ & $59.58 \pm 0.05$ \\
\hline 7 & $4-\mathrm{F}-\mathrm{C}_{6} \mathrm{H}_{4}$ & $10 \mathrm{~g}$ & $>100$ & $>100$ \\
\hline 8 & 3,4-diF- $\mathrm{C}_{6} \mathrm{H}_{3}$ & $10 \mathrm{~h}$ & $>100$ & $21.71 \pm 0.57$ \\
\hline 9 & $2-\mathrm{Cl}-\mathrm{C}_{6} \mathrm{H}_{4}$ & $10 \mathrm{i}$ & $>100$ & $>100$ \\
\hline 10 & $4-\mathrm{Cl}-\mathrm{C}_{6} \mathrm{H}_{4}$ & $10 \mathrm{j}$ & $>100$ & $>100$ \\
\hline 11 & $2-\mathrm{Br}-\mathrm{C}_{6} \mathrm{H}_{4}$ & $10 \mathrm{k}$ & $>100$ & $>100$ \\
\hline 12 & $3-\mathrm{Br}-\mathrm{C}_{6} \mathrm{H}_{4}$ & 101 & $>100$ & $65.96 \pm 0.004$ \\
\hline 13 & $4-\mathrm{Br}-\mathrm{C}_{6} \mathrm{H}_{4}$ & $10 \mathrm{~m}$ & $>100$ & $>100$ \\
\hline 14 & donepezil & & $0.079 \pm 0.002$ & $5.19 \pm 0.38$ \\
\hline
\end{tabular}

Data are expressed as mean \pm SD (three independent experiments)

The in vitro anti-ChE assay showed that the un-substituted benzyl derivative (10a) along with the metasubstituted analogs (10d, 10f, and 10l) had significant anti-BuChE activity. Introduction of extra small-size halogen groups such as $\mathrm{F}$ (compound 10h) resulted in the most potent activity with an $\mathrm{IC}_{50}$ value of $21.71 \mu \mathrm{M}$.

\section{Kinetic study of BuChE inhibition}

The kinetic study was performed to investigate the mechanism of inhibition by compound $\mathbf{1 0 h}$ against BuChE. Graphical analysis of the reciprocal Lineweaver-Burk plot of compound $\mathbf{1 0 h}$ described a mixed-type inhibition pattern (Fig. 2a) in which compound $\mathbf{1 0 h}$ may bound to the BuChE or it already bound to the substrate. Also, the $K i$ value was calculated using the secondary plot as $38.3 \mu \mathrm{M}$ (Fig. 2b)

\section{Inhibition of $A C h E$-induced and self-induced $A \beta$ aggregation} $\mathrm{A} \beta$ peptide is the major constituent of senile plaques in the brains of patients with AD. In this respect, the effect of the most potent compound $10 \mathrm{~h}$ was assessed for the inhibition against $A \beta_{1-42}$ aggregation and AChEinduced $A \beta_{1-40}$ peptide aggregation using the Thioflavin $\mathrm{T}$ (ThT) assay. Comparing with donepezil and tacrine as the reference compounds, it can be understood that 10h was more potent than both controls in inhibiting 

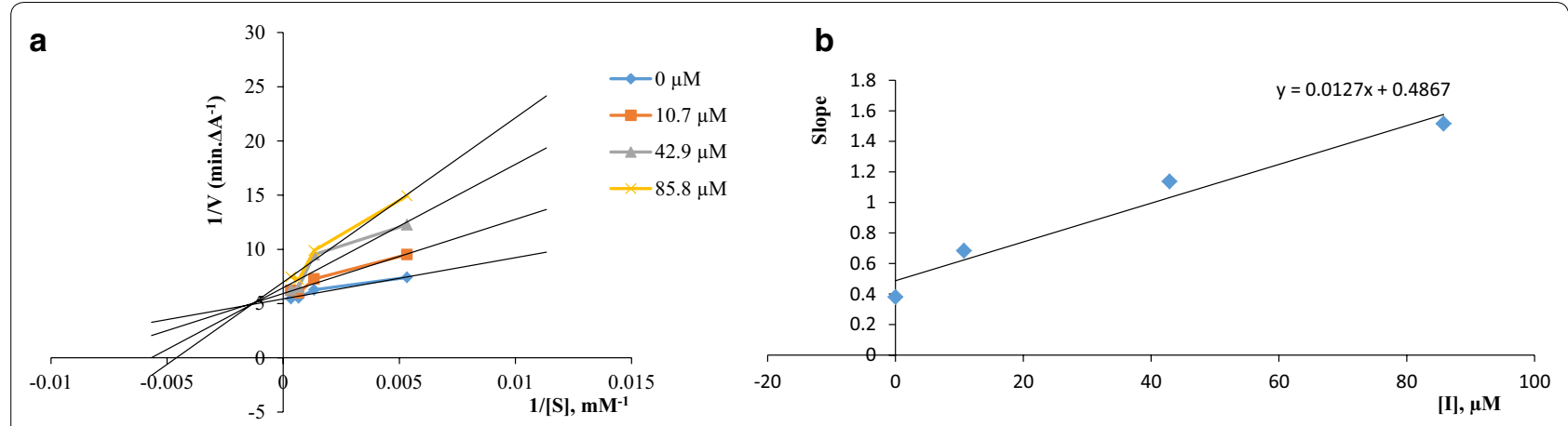

Fig. $\mathbf{2}$ a Kinetic study of BuChE inhibition by compound $\mathbf{1 0 h}$. b Inhibition constant (Ki) of compound $\mathbf{1 0 h}$

\begin{tabular}{|c|c|c|}
\hline Samples & $\begin{array}{l}\% \text { Inhibition self-induced } \\
A \beta_{1-42} \text { aggregation }\end{array}$ & $\begin{array}{l}\text { \% Inhibition } \\
\text { AChE-induced } A \beta \\
\text { aggregation }\end{array}$ \\
\hline $10 \mathrm{~h}$ & $32.6 \pm 2.0(10 \mu \mathrm{M})^{b}$ & $29.4 \pm 1.5(100 \mu \mathrm{M})^{c}$ \\
\hline Tacrine & $7.6 \pm 1.4(10 \mu \mathrm{M})$ & $6.7 \pm 0.9(100 \mu \mathrm{M})$ \\
\hline Donepezil & $18.1 \pm 1.4(10 \mu \mathrm{M})$ & $25.2 \pm 1.7(100 \mu \mathrm{M})$ \\
\hline
\end{tabular}

$\mathrm{A} \beta_{1-42}$ self-aggregation, as depicted $32.6 \%$ inhibition at $10 \mu \mathrm{M}$ (Table 2). Furthermore, compound 10h inhibited $\mathrm{AChE}$-induced $\mathrm{A} \beta$ aggregation by $29.4 \%$ at $100 \mu \mathrm{M}$.

\section{Neuroprotective studies on PC12 cell line}

Compound 10h was selected to study the neuroprotective ability using PC12 cell injury induced by $\mathrm{A} \beta_{25-35}$ by MTT assay. This compound depicted no neuroprotective effect on A $\beta$-induced on PC12 cells up to $50 \mu \mathrm{M}$. It can be understood that bioisosteric replacement of iminochromene moiety (compound F, Fig. 1) with chromenone ring did not induce the desired neuroprotectivity.

\section{Metal chelating}

Compound 10h was tested for its metal chelating ability towards $\mathrm{Fe}^{2+}, \mathrm{Cu}^{2+}$, and $\mathrm{Zn}^{2+}$ ions (Fig. 3) The UV spectrum of methanolic solution $(20 \mu \mathrm{M})$ of that compound showed two characteristic absorption peaks at 309.9 and $386.7 \mathrm{~nm}$. After the interaction of compound 10h with the above mentioned ions for $30 \mathrm{~min}$, small shifts as well as absorption intensity changes were observed in the spectra confirming biometal-ligand interactions.

Interaction of compound $10 \mathrm{~h}$ with $\mathrm{Zn}^{2+}$ ions demonstrated two absorption peaks at 299.2 and $388.7 \mathrm{~nm}$. Similar changes were observed in the case of $\mathrm{Fe}^{2+}$ ions and

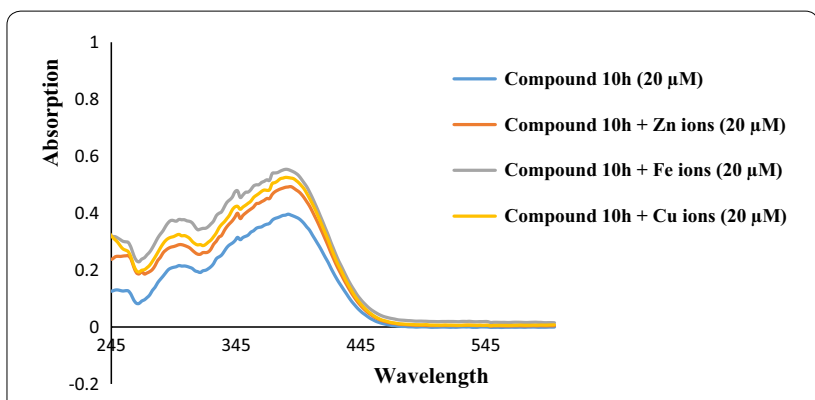

Fig. 3 The absorbance change of compound $\mathbf{1 0 h}$ alone and in the presence of $\mathrm{Zn}^{2+}, \mathrm{Fe}^{2+}$, and $\mathrm{Cu}^{2+}$ ions in the wavelength range from 200 to $600 \mathrm{~nm}$. The experiments were performed in triplicate

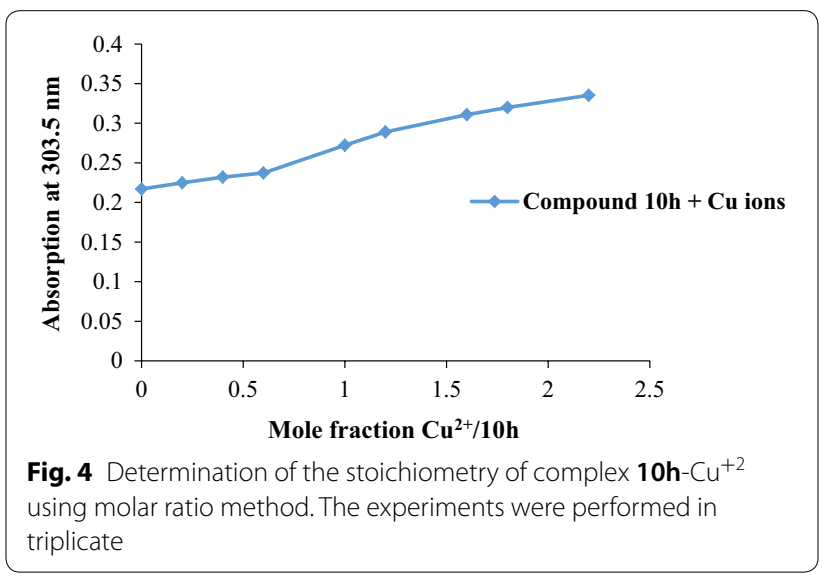

those absorptions were observed at 303.5 and $390.9 \mathrm{~nm}$. When compound $10 \mathrm{~h}$ was treated with $\mathrm{Cu}^{2+}$ ions, two peaks were observed at 303.5 and $382.4 \mathrm{~nm}$. The stoichiometry of complex $\mathbf{1 0 h}-\mathrm{Cu}^{2+}$ was also studied (Fig. 4) due to important role of copper ions in $\mathrm{AD}$ [38]. The concentration of the test compound 10h was $20 \mu \mathrm{M}$ and the final concentration of $\mathrm{Cu}^{2+}$ ranged from $0-44 \mu \mathrm{M}$ with $4 \mu \mathrm{M}$ intervals at $303.5 \mathrm{~nm}$. 
The plot was obtained by the corresponding absorption against the mole fraction of $\mathrm{Cu}^{2+}$ to ligand $\mathbf{1 0 h}$. According to the plot, the ratio 1:1 complexation ration of $\mathbf{1 0 h}$ $\mathrm{Cu}^{2+}$ can be seen at the fracture point of the plot with the mole fraction of 0.6 .

\section{Docking study of BuChE}

As discussed in the introduction and designing sections, the volume of the BuChE active site is considerably bigger than the one found in the AChE, so BuChE can accommodate bulkier inhibitors, and this may constitute the basis for the selectivity of these derivatives. An overlay of the best pose for $\mathbf{1 0 h}$ with BuChE was depicted in Fig. 5 . Chromenenone core is mostly surrounded by residues of CAS pocket, while 3,4-difluoro benzyl moiety oriented towards PAS pocket. More specifically, the carbonyl group of the chromenenone ring form a hydrogen bond with the oxygen of Ser198 of the CAS while the another hydrogen bond interaction was seen between the oxygen of chromenenone pendant group and Ser198. Also, the 1,2,3-triazole ring formed a third hydrogen bond with Trp82 of the anionic subsite.

The nitrogen of the dimethylamino propenone interacted with Pro285 via Van der Waals interaction. The Van der Waals interaction was also constructed between 1,2,3-triazole moiety and Ala326 of the PAS residue. The 3,4-difluoro benzyl ring also showed $\pi-\pi$ and van der Waals interactions with Tyr332. These results strongly supported the high potency of compound $10 \mathrm{~h}$ against BuChE.

It is concluded that not only dimethylamino propenone attached to the chromenone ring is an essential factor for designing an active and selective BuChE inhibitor,

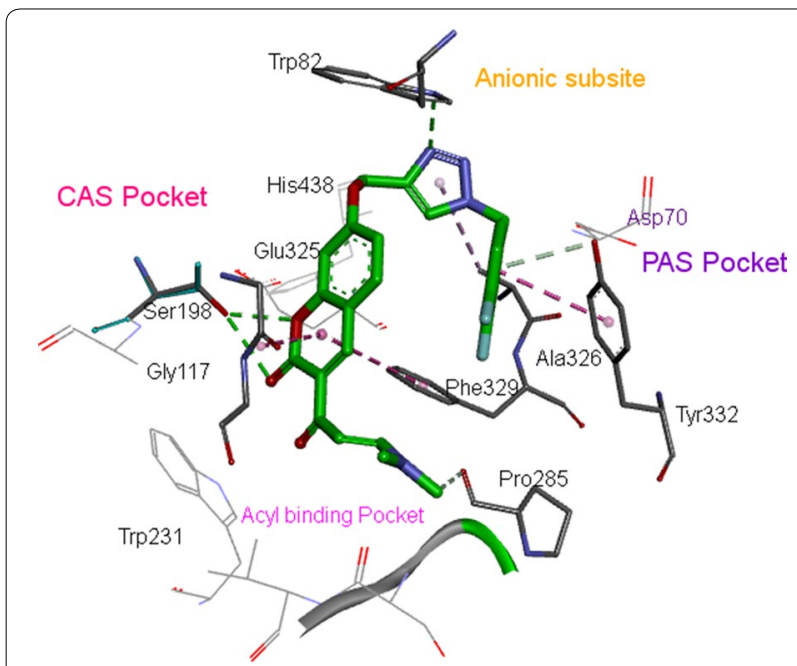

Fig. 5 Schematic representation showing interactions of compound 10h with the surrounding residues of BuChE (PDB code: 4BDS) [39] but also the nature of substituents on the aryl moieity connected to 1,2,3-triazole is the necessary element to afford a higher BuChE inhibitory effect. Further computer-aided lead optimization to improve anti-BuChE can be performed via replacing of the dimethylamino propenone pendant group with a cyclic amine to evaluate the size and bulkiness for the selective BuChE inhibition. Besides, the 1,2,3-triazole moiety can be substituted by different aliphatic spacer containing $\mathrm{CO}, \mathrm{NHCO}, \mathrm{NH}$ to improve the capability of $\mathrm{H}$-bonding interaction with the active site.

\section{In silico ADME evaluation}

In silico ADME/T studies of the synthesized compounds was performed using https://lmmd.ecust.edu.cn/admet sar2/ and https://preadmet.bmdrc.kr, to evaluate pharmacokinetic properties of possible and potential candidates/drug molecules which can be helpful for future anti-AD drug developments [40]. As shown in Table 3, most of the compounds showed drug-like characteristics based on Lipinski's rule of five $(\mathrm{MW}<500, \operatorname{cLogP}<5, \mathrm{HB}$ donor $\leq 5$, HB acceptor $\leq 10$ ). Our results indicated that lipophilicity and solubility of the derivatives were druglike. Furthermore, molecular weight, cLogP, and bloodbrain barrier were well within the standard ranges.

\section{Materials and methods} Instrumental methods

Melting points of synthesized compounds were determined on a Kofler hot stage apparatus. ${ }^{1} \mathrm{H}$ and ${ }^{13} \mathrm{C}$ NMR spectra were determined on a Varian FT-500, using TMS as an internal standard. IR spectra were recorded using KBr disks on a Bruker Tensor 27 FTIR spectrophotometer. Elemental analysis was carried out with an Elemental Analyzer system GmbH VarioEL CHN mode.

\section{Synthesis of 2-hydroxy-4-(prop-2-yn-1-yloxy)benzaldehyde} (3)

Compound 3 was prepared from the reaction of 2,4-dihydroxybenzaldehyde $\mathbf{1}$ and propargyl bromide $\mathbf{2}$ in the presence of potassium carbonate $\left(\mathrm{K}_{2} \mathrm{CO}_{3}\right)$ and potassium iodide (KI) in acetone at $50{ }^{\circ} \mathrm{C}$, according to the literature [34].

\section{Synthesis of 3-acetyl-7-(prop-2-yn-1-yloxy)-2H-chromen-2 -one (5)}

A few drops of piperidine were added to the mixture of compound 3 ( $1 \mathrm{mmol})$ and ethyl acetoacetate $(2.5 \mathrm{mmol})$ 4 in ethanol $(10 \mathrm{~mL})$ and it was stirred overnight at room temperature to obtain yellow precipitates. After completion of the reaction (checked by TLC), they were filtered off and used for the next step with no further purification. 
Table 3 Calculated molecular profile for synthesized compounds 10a-m

\begin{tabular}{llllllll}
\hline Compound & Descriptor & \multicolumn{7}{l}{} \\
\cline { 2 - 8 } & Mw & cLogP & $\begin{array}{l}\text { H-bond } \\
\text { acceptor }\end{array}$ & $\begin{array}{l}\text { H-Bond } \\
\text { Donor }\end{array}$ & BBB & $\begin{array}{l}\text { Human intestinal } \\
\text { absorption }\end{array}$ & Caco-2 permeability \\
\hline $\mathbf{1 0 a}$ & 430.46 & 3.27 & 8 & 0 & +0.9757 & +0.9298 & -0.8029 \\
$\mathbf{1 0 b}$ & 444.49 & 3.58 & 8 & 0 & +0.9754 & +0.9370 & -0.7985 \\
$\mathbf{1 0 c}$ & 444.49 & 3.58 & 8 & 0 & +0.9757 & +0.9370 & -0.7908 \\
$\mathbf{1 0 d}$ & 460.49 & 3.28 & 9 & 0 & +0.9757 & +0.9298 & -0.7587 \\
$\mathbf{1 0}$ & 448.45 & 3.41 & 8 & 0 & +0.9757 & +0.9294 & -0.8157 \\
$\mathbf{1 0 f}$ & 448.45 & 3.41 & 8 & 0 & +0.9757 & +0.9294 & -0.7970 \\
$\mathbf{1 0 g}$ & 448.45 & 3.41 & 8 & 0 & +0.9757 & +0.9294 & -0.8152 \\
$\mathbf{1 0 h}$ & 466.44 & 3.55 & 8 & 0 & +0.9757 & +0.9294 & -0.8211 \\
$\mathbf{1 0 i}$ & 464.91 & 3.92 & 8 & 0 & +0.9746 & +0.9319 & -0.8289 \\
$\mathbf{1 0 j}$ & 464.91 & 3.92 & 8 & 0 & +0.9746 & +0.9319 & -0.8211 \\
$\mathbf{1 0 k}$ & 509.36 & 4.03 & 8 & 0 & +0.9751 & +0.9131 & -0.8299 \\
$\mathbf{1 0}$ & 509.36 & 4.03 & 8 & 0 & +0.9751 & +0.9131 & -0.8115 \\
$\mathbf{1 0 m}$ & 509.36 & 4.03 & 8 & 0 & +0.9751 & +0.9131 & -0.8306 \\
\hline
\end{tabular}

It was also completely characterized and compared with reported in the literature [41].

\section{Synthesis of (E)-3-(3-(dimethylamino)acryloyl)-7-(prop-2-y} n-1-yloxy)-2H-chromen-2-one (7)

The mixture of compound 5 ( $1 \mathrm{mmo}$ ) and DMA-DMF 6 $(2 \mathrm{mmol})$ in 1,4-dioxane $(10 \mathrm{~mL})$ was heated at reflux for $6 \mathrm{~h}$. Then, the solvent was evaporated under vacuum and the residue was purified using plate chromatography with ethyl acetate as eluent.

Yield: 55\%; M.p. $98-100{ }^{\circ} \mathrm{C}$. IR (KBr): 2925, 2850, 2150, 1715, 1642, $1598 \mathrm{~cm}^{-1}$. ${ }^{1} \mathrm{H}$ NMR $\left(\mathrm{CDCl}_{3}, 500 \mathrm{MHz}\right)$ : $\delta=8.58(\mathrm{~s}, 1 \mathrm{H}, \mathrm{H} 4), 7.93(\mathrm{~d}, J=12.4 \mathrm{~Hz}, 1 \mathrm{H}, \mathrm{CH}), 7.54(\mathrm{~d}$, $J=8.3 \mathrm{~Hz}, 1 \mathrm{H}, \mathrm{H} 5), 6.93-6.91$ (m, 2H, H6, H8), $6.34(\mathrm{~d}$, $J=12.4 \mathrm{~Hz}, 1 \mathrm{H}, \mathrm{CH}), 4.77\left(\mathrm{~s}, 2 \mathrm{H}, \mathrm{CH}_{2}\right), 3.17\left(\mathrm{~s}, 3 \mathrm{H}, \mathrm{CH}_{3}\right)$, $2.97\left(\mathrm{~s}, 3 \mathrm{H}, \mathrm{CH}_{3}\right), 2.60(1 \mathrm{H}, \mathrm{CH}) \mathrm{ppm} .{ }^{13} \mathrm{C} \mathrm{NMR}\left(\mathrm{CDCl}_{3}\right.$, $125 \mathrm{MHz})$ : 182.3, 162.1, 160.1, 156.4, 155.0, 145.9, 131.1, $123.3,113.5,113.4,101.3,95.2,77.2,77.0,56.3,45.2$, $37.6 \mathrm{ppm}$.

\section{Synthesis}

\section{of 1,2,3-triazole-dimethylaminoacryloyl-chromenone} hybrids $10 \mathrm{a}-\mathrm{m}$

The final step was performed by the click reaction of compound 7 and in situ prepared azides 9. For this purpose, a solution of benzyl chloride/bromide derivative 8 (1.1 mmol), sodium azide $(0.06 \mathrm{~g}, 0.9 \mathrm{mmol})$, and triethylamine $(0.13 \mathrm{~g}, 1.3 \mathrm{mmol})$ in water $(4 \mathrm{~mL})$ and tertbutyl alcohol $(4 \mathrm{~mL})$ was stirred at room temperature for $30 \mathrm{~min}$. Then, compound $7(0.5 \mathrm{mmol})$ and $\mathrm{CuSO}_{4} \cdot 5 \mathrm{H}_{2} \mathrm{O}$ (7 mol\%) were added to the mixture and it was continued for $24 \mathrm{~h}$. Upon completion of the reaction checked TLC), the mixture was diluted with water, extracted with chloroform, and dried over anhydrous $\mathrm{Na}_{2} \mathrm{SO}_{4}$. After evaporation of the solvent, the residue was recrystallized from ethyl acetate and petroleum ether to give pure product 10. In the case of some compounds, they were purified using plate chromatography with ethyl acetate as eluent.

(E)-7-((1-Benzyl-1H-1,2,3-triazol-4-yl)

methoxy)-3-(3-(dimethylamino)

acryloyl)-2H-chromen-2-one (10a)

Yield: 54\%; M.p. $186-188{ }^{\circ} \mathrm{C}$. IR (KBr): 2920, 2853, 1715, 1640, 1597, $1558 \mathrm{~cm}^{-1}$. ${ }^{1} \mathrm{H}$ NMR $\left(\mathrm{CDCl}_{3}, 500 \mathrm{MHz}\right)$ : $\delta=8.55(\mathrm{~s}, 1 \mathrm{H}$, triazole), $7.91(\mathrm{~d}, J=12.5 \mathrm{~Hz}, 1 \mathrm{H}, \mathrm{CH})$, 7.60 (s, 1H, H4), 7.50 (d, 1H, J=8.5 Hz, H5), 7.38-7.29 (m, 5H, H2' $\left.\mathrm{H}^{\prime}, \mathrm{H}^{\prime}, \mathrm{H}^{\prime}, \mathrm{H6}^{\prime}\right), 6.92-6.90$ (m, 2H, H6, $\mathrm{H} 8), 6.33$ (d, $J=12.5 \mathrm{~Hz}, 1 \mathrm{H}, \mathrm{CH}), 5.55\left(\mathrm{~s}, 2 \mathrm{H}, \mathrm{CH}_{2}\right), 5.24$ (s, $2 \mathrm{H}, \mathrm{CH}_{2}$ ), 3.17 (s, 3H, $\left.\mathrm{CH}_{3}\right), 2.96\left(\mathrm{~s}, 3 \mathrm{H}, \mathrm{CH}_{3}\right) \mathrm{ppm}$. ${ }^{13} \mathrm{C}$ NMR $\left(\mathrm{CDCl}_{3}, 125 \mathrm{MHz}\right): \delta=182.4,171.7,162.9$, $156.2,151.4,145.6,144.0,134.7,133.3,131.1,129.8$, 128.9, 128.2, 122.6, 121.5, 113.3, 101.2, 92.2, 63.4, 57.2, 47.6, 38.1 ppm. Anal. calcd. for $\mathrm{C}_{24} \mathrm{H}_{22} \mathrm{~N}_{4} \mathrm{O}_{4}$ : C, 66.97; $\mathrm{H}$, $5.15 ; \mathrm{N}, 13.02$. Found: C, 66.71; H, 5.38; N, 12.86 .

\section{(E)-3-(3-(Dimethylamino)}

acryloyl)-7-((1-(2-methylbenzyl)-1H-1,2,3-triazol-4-yl) methoxy)-2H-chromen-2-one (10b)

Yield: 59\%; M.p. 203-205 ${ }^{\circ} \mathrm{C}$. IR (KBr): 2924, 2855, 1712, 1640, 1596, $1558 \mathrm{~cm}^{-1}$. ${ }^{1} \mathrm{H}$ NMR $\left(\mathrm{CDCl}_{3}, 500 \mathrm{MHz}\right)$ : $\delta=8.58(\mathrm{~s}, 1 \mathrm{H}$, triazole), $7.92(\mathrm{~d}, J=12.3 \mathrm{~Hz}, 1 \mathrm{H}, \mathrm{CH})$, 7.52 (d, 1H, J=8.3 Hz, H5), 7.46 (s, 1H, H4), 7.32-7.18 (m, 4H, H3', H4', H5', H6'), 6.93-6.91 (m, 2H, H6, H8), 6.35 (d, J=12.3 Hz, 1H, CH), 5.57 (s, 2H, $\left.\mathrm{CH}_{2}\right), 5.24$ (s, $2 \mathrm{H}, \mathrm{CH}_{2}$ ) $3.18\left(\mathrm{~s}, 3 \mathrm{H}, \mathrm{CH}_{3}\right), 2.98\left(\mathrm{~s}, 3 \mathrm{H}, \mathrm{CH}_{3}\right), 2.29$ (s, 
$\left.3 \mathrm{H}, \mathrm{CH}_{3}\right) \mathrm{ppm} .{ }^{13} \mathrm{C}$ NMR $\left(\mathrm{CDCl}_{3}, 125 \mathrm{MHz}\right): \delta=182.4$, $162.4,160.2,156.5,154.9,145.9,143.0,137.0,132.0$, $131.1,130.7,129.5,129.3,126.7,123.5,122.7,113.3$, 113.0, 101.3, 95.2, 62.4, 52.5, 45.3, 37.6, 19.0 ppm. Anal. calcd. for $\mathrm{C}_{25} \mathrm{H}_{24} \mathrm{~N}_{4} \mathrm{O}_{4}: \mathrm{C}, 67.55 ; \mathrm{H}, 5.44 ; \mathrm{N}, 12.60$. Found: C, 67.31; H, 5.70; N, 12.44 .

\section{(E)-3-(3-(Dimethylamino)}

acryloyl)-7-((1-(4-methylbenzyl)-1H-1,2,3-triazol-4-yl) methoxy)-2H-chromen-2-one (10c)

Yield: 55\%; M.p. $199-201{ }^{\circ} \mathrm{C}$. IR (KBr): 2923, 2855, 1715, 1640, 1596, $1558 \mathrm{~cm}^{-1} .{ }^{1} \mathrm{H}$ NMR $\left(\mathrm{CDCl}_{3}, 500 \mathrm{MHz}\right)$ : $\delta=8.57(\mathrm{~s}, 1 \mathrm{H}$, triazole), $7.92(\mathrm{~d}, J=12.3 \mathrm{~Hz}, 1 \mathrm{H}, \mathrm{CH})$, 7.55 (s, 1H, H4), 7.51 (d, 1H, J=8.3 Hz, H5), 7.19-7.17 (m, 4H, H2', H3', H5', H6'), 6.94-6.91 (m, 2H, H6, H8), $6.34(\mathrm{~d}, J=12.3 \mathrm{~Hz}, 1 \mathrm{H}, \mathrm{CH}), 5.51\left(\mathrm{~s}, 2 \mathrm{H}, \mathrm{CH}_{2}\right), 5.24(\mathrm{~s}$, $\left.2 \mathrm{H}, \mathrm{CH}_{2}\right), 3.17\left(\mathrm{~s}, 3 \mathrm{H}, \mathrm{CH}_{3}\right), 2.97\left(\mathrm{~s}, 3 \mathrm{H}, \mathrm{CH}_{3}\right), 2.36(\mathrm{~s}$, $\left.3 \mathrm{H}, \mathrm{CH}_{3}\right) \mathrm{ppm} .{ }^{13} \mathrm{C} \mathrm{NMR}\left(\mathrm{CDCl}_{3}, 125 \mathrm{MHz}\right): \delta=182.5$, 162.4, 160.2, 156.6, 1549, 145.9, 143.1, 138.9, 131.2, 130.7, $129.8,128.2,123.3,122.8,113.3,133.2,101.2,95.2,62.4$, 54.6, 45.6, 37.6, $21.2 \mathrm{ppm}$. Anal. calcd. for $\mathrm{C}_{25} \mathrm{H}_{24} \mathrm{~N}_{4} \mathrm{O}_{4}$ : C, 67.55; H, 5.44; N, 12.60. Found: C, 67.40; H, 5.26; N, 12.71 .

\section{(E)-3-(3-(Dimethylamino)}

acryloyl)-7-((1-(3-methoxybenzyl)-1H-1,2,3-triazol-4-yl) methoxy)-2H-chromen-2-one (10d)

Yield: 52\%; M.p. $209-211{ }^{\circ} \mathrm{C}$. IR (KBr): 2923, 2855, 1712, 1640, 1595, $1557 \mathrm{~cm}^{-1}$. ${ }^{1} \mathrm{H}$ NMR $\left(\mathrm{CDCl}_{3}, 500 \mathrm{MHz}\right)$ : $\delta=8.57(\mathrm{~s}, 1 \mathrm{H}$, triazole), $7.92(\mathrm{~d}, J=12.4 \mathrm{~Hz}, 1 \mathrm{H}, \mathrm{CH})$, 7.59 (s, $1 \mathrm{H}, \mathrm{H} 4), 7.52(\mathrm{~d}, 1 \mathrm{H}, J=8.4 \mathrm{~Hz}, \mathrm{H} 5), 7.30(\mathrm{t}$, $\left.J=7.9 \mathrm{~Hz}, 1 \mathrm{H}, \mathrm{H} 5^{\prime}\right), 6.94-6.81$ (m, 5H, H6, H8, H2', H4', $\left.\mathrm{H}^{\prime}\right), 6.35(\mathrm{~d}, J=12.4 \mathrm{~Hz}, 1 \mathrm{H}, \mathrm{CH}), 5.52\left(\mathrm{~s}, 2 \mathrm{H}, \mathrm{CH}_{2}\right)$, $5.25\left(\mathrm{~s}, 2 \mathrm{H}, \mathrm{CH}_{2}\right), 3.79\left(\mathrm{~s}, 3 \mathrm{H}, \mathrm{OCH}_{3}\right), 3.17\left(\mathrm{~s}, 3 \mathrm{H}, \mathrm{CH}_{3}\right)$, $2.97\left(\mathrm{~s}, 3 \mathrm{H}, \mathrm{CH}_{3}\right)$ ppm. ${ }^{13} \mathrm{C} \mathrm{NMR}\left(\mathrm{CDCl}_{3}, 125 \mathrm{MHz}\right)$ : $\delta=182.4,162.4,160.2,156.6,154.9,145.9,144.0,143.2$, $135.7,130.7,130.3,123.4,122.9,119.3,114.3,113.8$, 133.3, 112.5, 101.2, 95.2, 62.4, 55.3, 54.3, 45.2, 37.6 ppm. Anal. calcd. for $\mathrm{C}_{25} \mathrm{H}_{24} \mathrm{~N}_{4} \mathrm{O}_{5}: \mathrm{C}, 65.21 ; \mathrm{H}, 5.25 ; \mathrm{N}, 12.17$. Found: C, 65.41; H, 5.10; N, 12.32 .

\section{(E)-3-(3-(Dimethylamino)}

\section{acryloyl)-7-((1-(2-fluorobenzyl)-1H-1,2,3-triazol-4-yl)} methoxy)-2H-chromen-2-one (10e)

Yield: $55 \%$; M.p. $180-183{ }^{\circ} \mathrm{C}$. IR (KBr): 2924, 2852, 1712, 1640, 1597, $1558 \mathrm{~cm}^{-1}$. ${ }^{1} \mathrm{H}$ NMR $\left(\mathrm{CDCl}_{3}, 500 \mathrm{MHz}\right)$ : $\delta=8.57(\mathrm{~s}, 1 \mathrm{H}$, triazole), $7.91(\mathrm{~d}, J=12.4 \mathrm{~Hz}, 1 \mathrm{H}, \mathrm{CH})$, $7.67(\mathrm{~s}, 1 \mathrm{H}, \mathrm{H} 4), 7.51(\mathrm{~d}, 1 \mathrm{H}, J=8.0 \mathrm{~Hz}, \mathrm{H} 5), 7.39-7.38$ $\left(\mathrm{m}, 1 \mathrm{H}, \mathrm{H} 4^{\prime}\right), 7.30\left(\mathrm{td}, J=7.6,1.5 \mathrm{~Hz}, 1 \mathrm{H}, \mathrm{H3} 3^{\prime}\right), 7.17-$ 7.11 (m, 2H, H5' $\mathrm{H}^{\prime}$ ), 6.94-6.92 (m, 2H, H6, H8), 6.34 (d, $J=12.4 \mathrm{~Hz}, 1 \mathrm{H}, \mathrm{CH}), 5.61\left(\mathrm{~s}, 2 \mathrm{H}, \mathrm{CH}_{2}\right), 5.25(\mathrm{~s}, 2 \mathrm{H}$, $\mathrm{CH}_{2}$ ), 3.17 (s, $\left.3 \mathrm{H}, \mathrm{CH}_{3}\right), 2.97$ (s, $\left.3 \mathrm{H}, \mathrm{CH}_{3}\right)$ ppm. ${ }^{13} \mathrm{C}$
$\operatorname{NMR}\left(\mathrm{CDCl}_{3}, 125 \mathrm{MHz}\right): \delta=182.3,162.4,160.6\left(\mathrm{~d}, J_{C-}\right.$ $\left.{ }_{F}=251.2 \mathrm{~Hz}\right), 160.1,158.7,156.6,154.8,145.9,143.2$, $131.1\left(\mathrm{~d}, J_{C-F}=8.1 \mathrm{~Hz}\right), 130.7\left(\mathrm{~d}, J_{C-F}=3.3 \mathrm{~Hz}\right), 124.9(\mathrm{~d}$, $\left.J_{C-F}=3.4 \mathrm{~Hz}\right), 123.3,121.3,121.6\left(\mathrm{~d}, J_{C-F}=14.5 \mathrm{~Hz}\right), 115.9$ $\left(\mathrm{d}, J_{C-F}=21.03 \mathrm{~Hz}\right), 113.3,113.2,101.2,95.2,62.4,47.9$, 45.2, 37.5 ppm. Anal. calcd. for $\mathrm{C}_{24} \mathrm{H}_{21} \mathrm{FN}_{4} \mathrm{O}_{4}$ : C, 64.28; H, 4.72; N, 12.49. Found: C, 64.36; H, 4.57; N, 12.55 .

\section{(E)-3-(3-(Dimethylamino)}

acryloyl)-7-((1-(3-fluorobenzyl)-1H-1,2,3-triazol-4-yl) methoxy)-2H-chromen-2-one (10f)

Yield: $60 \%$; M.p. $183-185{ }^{\circ} \mathrm{C}$. IR (KBr): 2922, 2850 , 1713, 1640, $1597 \mathrm{~cm}^{-1} .{ }^{1} \mathrm{H}$ NMR $\left(\mathrm{CDCl}_{3}, 500 \mathrm{MHz}\right)$ : $\delta=8.57(\mathrm{~s}, 1 \mathrm{H}$, triazole), $7.91(\mathrm{~d}, J=12.3 \mathrm{~Hz}, 1 \mathrm{H}, \mathrm{CH})$, $7.61(\mathrm{~s}, 1 \mathrm{H}, \mathrm{H} 4), 7.51(\mathrm{~d}, 1 \mathrm{H}, J=8.3 \mathrm{~Hz}, \mathrm{H} 5), 7.36(\mathrm{td}$, $\left.1 \mathrm{H}, J=7.5,2.2 \mathrm{~Hz}, \mathrm{H} 5^{\prime}\right), 7.08-7.04\left(\mathrm{~m}, 2 \mathrm{H}, \mathrm{H} 4^{\prime}, \mathrm{H} 6^{\prime}\right.$ ), $6.97\left(\mathrm{~d}, 1 \mathrm{H}, J=9.2 \mathrm{~Hz}, \mathrm{H} 2^{\prime}\right), 6.94-6.91(\mathrm{~m}, 2 \mathrm{H}, \mathrm{H} 6, \mathrm{H} 8)$, $6.34(\mathrm{~d}, J=12.3 \mathrm{~Hz}, 1 \mathrm{H}, \mathrm{CH}), 5.55\left(\mathrm{~s}, 2 \mathrm{H}, \mathrm{CH}_{2}\right), 5.26(\mathrm{~s}$, $\left.2 \mathrm{H}, \mathrm{CH}_{2}\right), 3.17\left(\mathrm{~s}, 3 \mathrm{H}, \mathrm{CH}_{3}\right), 2.96\left(\mathrm{~s}, 3 \mathrm{H}, \mathrm{CH}_{3}\right) \mathrm{ppm} .{ }^{13} \mathrm{C}$ $\operatorname{NMR}\left(\mathrm{CDCl}_{3}, 125 \mathrm{MHz}\right): \delta=180.0,162.3,160.7\left(\mathrm{~d}, J_{C-}\right.$ $\left.{ }_{F}=262.2 \mathrm{~Hz}\right), 160.1,156.7,154.9,145.8,143.5,136.6(\mathrm{~d}$, $\left.J_{C-F}=19.4 \mathrm{~Hz}\right), 130.8\left(\mathrm{~d}, J_{C-F}=8.1 \mathrm{~Hz}\right), 130.7,123.6,123.3$, $122.9,115.9\left(\mathrm{~d}, J_{C-F}=20.9 \mathrm{~Hz}\right), 115.1\left(\mathrm{~d}, J_{C-F}=22.0 \mathrm{~Hz}\right)$, 113.3, 113.2, 101.2, 95.2, 62.4, 53.7, 45.0, 37.6 ppm. Anal. calcd. for $\mathrm{C}_{24} \mathrm{H}_{21} \mathrm{FN}_{4} \mathrm{O}_{4}$ : C, 64.28; $\mathrm{H}, 4.72 ; \mathrm{N}, 12.49$. Found: C, 64.47; H, 4.84; N, 12.60 .

\section{(E)-3-(3-(Dimethylamino)}

acryloyl)-7-((1-(4-fluorobenzyl)-1H-1,2,3-triazol-4-yl) methoxy)-2H-chromen-2-one (10g)

Yield: $62 \%$; M.p. $183-185{ }^{\circ} \mathrm{C}$. IR (KBr): 2923, 2855, 1714, 1640, $1598 \mathrm{~cm}^{-1} .{ }^{1} \mathrm{H}$ NMR $\left(\mathrm{CDCl}_{3}, 500 \mathrm{MHz}\right): \delta=8.56$ (s, $1 \mathrm{H}$, triazole), $7.92(\mathrm{~d}, J=12.4 \mathrm{~Hz}, 1 \mathrm{H}, \mathrm{CH}), 7.58(\mathrm{~s}, 1 \mathrm{H}$, H4), 7.51 (d, $1 \mathrm{H}, J=8.4 \mathrm{~Hz}, \mathrm{H} 5), 7.29$ (dd, $J=8.7,5.1 \mathrm{~Hz}$, $\left.2 \mathrm{H}, \mathrm{H} 2^{\prime}, \mathrm{H}^{\prime}\right), 7.07$ (t, $\left.J=8.7 \mathrm{~Hz}, 2 \mathrm{H}, \mathrm{H} 3^{\prime}, \mathrm{H}^{\prime}\right), 6.93-6.91$ (m, 2H, H6, H8), $6.33(\mathrm{~d}, J=12.4 \mathrm{~Hz}, 1 \mathrm{H}, \mathrm{CH}), 5.52(\mathrm{~s}$, $\left.2 \mathrm{H}, \mathrm{CH}_{2}\right), 5.24\left(\mathrm{~s}, 2 \mathrm{H}, \mathrm{CH}_{2}\right), 3.16\left(\mathrm{~s}, 3 \mathrm{H}, \mathrm{CH}_{3}\right), 2.96(\mathrm{~s}$, $\left.3 \mathrm{H}, \mathrm{CH}_{3}\right)$ ppm. ${ }^{13} \mathrm{C} \mathrm{NMR}\left(\mathrm{CDCl}_{3}, 125 \mathrm{MHz}\right): \delta=180.1$, $162.4,160.5\left(\mathrm{~d}, J_{C-F}=260.5 \mathrm{~Hz}\right), 160.1,156.5,154.8$, $145.1,143.4,134.5\left(\mathrm{~d}, J_{C-F}=19.5 \mathrm{~Hz}\right), 130.7,130.1,123.3$, $122.8,116.2\left(\mathrm{~d}, J_{C-F}=21.0 \mathrm{~Hz}\right), 113.3,113.2,101.2,95.1$, 62.1, 53.5, 45.0, 37.5 ppm. Anal. calcd. for $\mathrm{C}_{24} \mathrm{H}_{21} \mathrm{FN}_{4} \mathrm{O}_{4}$ : C, 64.28; H, 4.72; N, 12.49. Found: C, 64.44; H, 4.60; N, 12.27 .

\section{(E)-7-((1-(3,4-Difluorobenzyl)-1H-1,2,3-triazol-4-yl) methoxy)-3-(3-(dimethylamino) acryloyl)-2H-chromen-2-one (10h)}

Yield: 59\%; M.p. $188-190{ }^{\circ} \mathrm{C}$. IR (KBr): 2922, 2850, 1718, 1640, $1594 \mathrm{~cm}^{-1} \cdot{ }^{1} \mathrm{H}$ NMR $\left(\mathrm{CDCl}_{3}, 500 \mathrm{MHz}\right): \delta=8.57$ (s, $1 \mathrm{H}$, triazole), $7.91(\mathrm{~d}, J=12.3 \mathrm{~Hz}, 1 \mathrm{H}, \mathrm{CH}), 7.63(\mathrm{~s}, 1 \mathrm{H}$, $\mathrm{H} 4), 7.52(\mathrm{~d}, 1 \mathrm{H}, J=8.4 \mathrm{~Hz}, \mathrm{H} 5), 7.21-7.11\left(\mathrm{~m}, 2 \mathrm{H}, \mathrm{H} 5^{\prime}\right.$, H6'), 7.06-7.04 (m, 1H, H2'), 6.93-6.91 (m, 2H, H6, H8), 
$6.33(\mathrm{~d}, J=12.3 \mathrm{~Hz}, 1 \mathrm{H}, \mathrm{CH}), 5.52\left(\mathrm{~s}, 2 \mathrm{H}, \mathrm{CH}_{2}\right), 5.27(\mathrm{~s}$, $\left.2 \mathrm{H}, \mathrm{CH}_{2}\right), 3.18\left(\mathrm{~s}, 3 \mathrm{H}, \mathrm{CH}_{3}\right), 2.97\left(\mathrm{~s}, 3 \mathrm{H}, \mathrm{CH}_{3}\right) \mathrm{ppm} .{ }^{13} \mathrm{C}$ $\operatorname{NMR}\left(\mathrm{CDCl}_{3}, 125 \mathrm{MHz}\right): \delta=182.3,160.1,156.6,154.9$, $150.5\left(\mathrm{~d}, J_{C-F}=243.1 \mathrm{~Hz}\right), 149.6,\left(\mathrm{~d}, J_{C-F}=240.0 \mathrm{~Hz}\right), 145.8$, 144.0, 143.6, 132.8, 131.2, 130.7, 124.3, 123.4, 122.9, 118.1 (d, $\left.J_{C-F}=17.2\right), 117.3$ (d, $\left.J_{C-F}=17.6\right), 113.3,101.2$, 95.2, 62.4, 53.2, 45.2, 37.6 ppm. Anal. calcd. for $\mathrm{C}_{24} \mathrm{H}_{20} \mathrm{~F}_{2} \mathrm{~N}_{4} \mathrm{O}_{4}$ : C, 61.80; H, 4.32; N, 12.01. Found: C, 61.63; H, 4.17; N, 11.84 .

\section{(E)-7-((1-(2-Chlorobenzyl)-1H-1,2,3-triazol-4-yl) methoxy)-3-(3-(dimethylamino) acryloyl)-2H-chromen-2-one (10i)}

Yield: 58\%; M.p. $178-180{ }^{\circ} \mathrm{C}$. IR (KBr): 2923, 2852, 1713, 1640, $1597 \mathrm{~cm}^{-1}$. ${ }^{1} \mathrm{H}$ NMR $\left(\mathrm{CDCl}_{3}, 500 \mathrm{MHz}\right): \delta=8.60$ (s, $1 \mathrm{H}$, triazole), $7.91(\mathrm{~d}, J=11.0 \mathrm{~Hz}, 1 \mathrm{H}, \mathrm{CH}), 7.68(\mathrm{~s}, 1 \mathrm{H}$, H4), 7.51 (d, $1 \mathrm{H}, J=8.1 \mathrm{~Hz}, \mathrm{H} 5), 7.43$ (d, $1 \mathrm{H}, J=7.9 \mathrm{~Hz}$, $\mathrm{H}^{\prime}$ ), 7.32-7.24 (m, 3H, H4', H5' $\left.{ }^{\prime} \mathrm{H}^{\prime}\right), 6.93-6.87$ (m, 2H, H6, H8), 6.33 (d, J=11.0 Hz, 1H, CH), 5.69 (s, 2H, $\mathrm{CH}_{2}$ ), 5.29 (s, $\left.2 \mathrm{H}, \mathrm{CH}_{2}\right), 3.16\left(\mathrm{~s}, 3 \mathrm{H}, \mathrm{CH}_{3}\right), 2.96(\mathrm{~s}, 3 \mathrm{H}$, $\left.\mathrm{CH}_{3}\right) \mathrm{ppm} .{ }^{13} \mathrm{C} \mathrm{NMR}\left(\mathrm{CDCl}_{3}, 125 \mathrm{MHz}\right): \delta=182.7,171.5$, 163.8, 158.5, 156.3, 151.7, 144.5, 133.6, 131.7, 130.7, 130.5, $130.4,130.0,127.7,123.4,120.1,113.3,112.8,100.6,96.6$, 61.1, 52.3, 46.4, 40.4 ppm. Anal. calcd. for $\mathrm{C}_{24} \mathrm{H}_{21} \mathrm{ClN}_{4} \mathrm{O}_{4}$ : C, 62.00; H, 4.55; N, 12.05. Found: C, 61.81; H, 4.38; N, 11.90 .

(E)-7-((1-(4-Chlorobenzyl)-1H-1,2,3-triazol-4-yl)

methoxy)-3-(3-(dimethylamino)

acryloyl)-2H-chromen-2-one (10j)

Yield: 61\%; M.p. $178-180{ }^{\circ} \mathrm{C}$. IR (KBr): 2891, 2850, 1715, 1640, 1597, $1558 \mathrm{~cm}^{-1}$. ${ }^{1} \mathrm{H}$ NMR $\left(\mathrm{CDCl}_{3}, 500 \mathrm{MHz}\right)$ : $\delta=8.54(\mathrm{~s}, 1 \mathrm{H}$, triazole), $7.90(\mathrm{~d}, J=12.4 \mathrm{~Hz}, 1 \mathrm{H}, \mathrm{CH})$, 7.61 (s, 1H, H4), 7.50 (d, J=8.5 Hz, 1H, H5), $7.34(\mathrm{~d}$, $\left.J=8.1 \mathrm{~Hz}, 2 \mathrm{H}, \mathrm{H}^{\prime}, \mathrm{H}^{\prime}\right), 7.22\left(\mathrm{~d}, J=8.1 \mathrm{~Hz}, 2 \mathrm{H}, \mathrm{H} 2^{\prime}\right.$, $\left.\mathrm{H} 6^{\prime}\right)$,

6.92-6.89 (m, 2H, H6, H8), $6.34(\mathrm{~d}, J=12.4 \mathrm{~Hz}$, $1 \mathrm{H}, \mathrm{CH}), 5.52\left(\mathrm{~s}, 2 \mathrm{H}, \mathrm{CH}_{2}\right), 5.19\left(\mathrm{~s}, 2 \mathrm{H}, \mathrm{CH}_{2}\right), 3.11(\mathrm{~s}$, $\left.3 \mathrm{H}, \mathrm{CH}_{3}\right), 2.95\left(\mathrm{~s}, 3 \mathrm{H}, \mathrm{CH}_{3}\right)$ ppm. ${ }^{13} \mathrm{C} \mathrm{NMR}\left(\mathrm{CDCl}_{3}\right.$, $125 \mathrm{MHz}): \delta=182.9,162.4,160.1,156.5,154.9,145.8$, $144.2,143.4,134.9,130.7,129.5,129.4,123.3,122.9$, 113.3, 133.2, 101.2, 95.2, 62.4, 53.5, 45.2, 37.6 ppm. Anal. calcd. for $\mathrm{C}_{24} \mathrm{H}_{21} \mathrm{ClN}_{4} \mathrm{O}_{4}: \mathrm{C}, 62.00 ; \mathrm{H}, 4.55 ; \mathrm{N}, 12.05$. Found: C, 62.11; H, 4.40; N, 12.28.

(E)-7-((1-(2-Bromobenzyl)-1H-1,2,3-triazol-4-yl)

methoxy)-3-(3-(dimethylamino)

acryloyl)-2H-chromen-2-one (10k)

Yield: 58\%; M.p. 202-205 ${ }^{\circ} \mathrm{C}$. IR (KBr): 2924, 2850, 1709, 1641, 1598, $1559 \mathrm{~cm}^{-1}$. ${ }^{1} \mathrm{H}$ NMR $\left(\mathrm{CDCl}_{3}, 500 \mathrm{MHz}\right)$ : $\delta=8.57(\mathrm{~s}, 1 \mathrm{H}$, triazole), $7.92(\mathrm{~d}, J=12.3 \mathrm{~Hz}, 1 \mathrm{H}, \mathrm{CH})$, 7.70 (s, 1H, H4), 7.63 (d, 1H, J=7.5 Hz, H3'), 7.52 (d,
$1 \mathrm{H}, J=8.3 \mathrm{~Hz}, \mathrm{H} 5), 7.33\left(\mathrm{t}, 1 \mathrm{H}, J=7.5 \mathrm{~Hz}, \mathrm{H} 5^{\prime}\right), 7.25-$ 7.21 (m, 2H, H4', H6'), 6.95-6.93 (m, 2H, H6, H8), 6.34 $(\mathrm{d}, J=12.3 \mathrm{~Hz}, 1 \mathrm{H}, \mathrm{CH}), 5.69\left(\mathrm{~s}, 2 \mathrm{H}, \mathrm{CH}_{2}\right), 5.27(\mathrm{~s}, 2 \mathrm{H}$, $\mathrm{CH}_{2}$ ), 3.21 (s, 3H, $\left.\mathrm{CH}_{3}\right), 2.97\left(\mathrm{~s}, 3 \mathrm{H}, \mathrm{CH}_{3}\right)$ ppm. ${ }^{13} \mathrm{C} \mathrm{NMR}$ $\left(\mathrm{CDCl}_{3}, 125 \mathrm{MHz}\right): \delta=182.5,162.4,160.1,156.6,154.9$, $145.9,143.1,133.8,133.4,133.3,130.7,130.6,130.5$, 128.3, 123.6, 123.3, 113.4, 113.3, 100.4, 95.2, 62.0, 54.0, 44.8, 37.2 ppm. Anal. calcd. for $\mathrm{C}_{24} \mathrm{H}_{21} \mathrm{BrN}_{4} \mathrm{O}_{4}$ : C, 56.59; H, 4.16; N, 11.00. Found: C, 56.37; H, 4.30; N, 11.21.

\section{(E)-7-((1-(3-Bromobenzyl)-1H-1,2,3-triazol-4-yl) methoxy)-3-(3-(dimethylamino) acryloyl)-2H-chromen-2-one (10I)}

Yield: 64\%; M.p. $218-220{ }^{\circ} \mathrm{C}$. IR (KBr): 2925, 2856, 1710, 1640, $1595 \mathrm{~cm}^{-1} .{ }^{1} \mathrm{H}$ NMR $\left(\mathrm{CDCl}_{3}, 500 \mathrm{MHz}\right): \delta=8.59$ (s, $1 \mathrm{H}$, triazole), $7.93(\mathrm{~d}, J=12.4 \mathrm{~Hz}, 1 \mathrm{H}, \mathrm{CH}), 7.61(\mathrm{~s}, 1 \mathrm{H}$, H4), 7.55-7.51 (m, 3H, H5, H2', H4'), 7.26-7.18 (m, 2H, $\left.\mathrm{H} 5^{\prime}, \mathrm{H6}^{\prime}\right), 6.96-6.94(\mathrm{~m}, 2 \mathrm{H}, \mathrm{H} 6, \mathrm{H} 8), 6.35$ (d, J=12.4 Hz, $1 \mathrm{H}, \mathrm{CH}), 5.51\left(\mathrm{~s}, 2 \mathrm{H}, \mathrm{CH}_{2}\right), 5.28\left(\mathrm{~s}, 2 \mathrm{H}, \mathrm{CH}_{2}\right), 3.19(\mathrm{~s}$, $\left.3 \mathrm{H}, \mathrm{CH}_{3}\right), 2.98\left(\mathrm{~s}, 3 \mathrm{H}, \mathrm{CH}_{3}\right)$ ppm. ${ }^{13} \mathrm{C} \mathrm{NMR}\left(\mathrm{CDCl}_{3}\right.$, $125 \mathrm{MHz}): \delta=180.1,162.3,160.2,156.5,154.9,145.9$, $143.5,136.4,133.7,132.1,131.1,130.9,130.8,126.6$, 122.9, 122.2, 113.4, 113.3, 101.1, 95.0, 62.8, 53.6, 44.8, 38.8 ppm. Anal. calcd. for $\mathrm{C}_{24} \mathrm{H}_{21} \mathrm{BrN}_{4} \mathrm{O}_{4}: \mathrm{C}, 56.59 ; \mathrm{H}$, $4.16 ; \mathrm{N}, 11.00$. Found: C, 56.31; H, 4.24; N, 11.18 .

\section{(E)-7-((1-(4-Bromobenzyl)-1H-1,2,3-triazol-4-yl) methoxy)-3-(3-(dimethylamino) acryloyl)-2H-chromen-2-one (10m)}

Yield: $64 \%$; M.p. $173-175^{\circ} \mathrm{C}$. IR (KBr): 2925, 2850, 1715, 1640, $1597 \mathrm{~cm}^{-1}$. ${ }^{1} \mathrm{H}$ NMR $\left(\mathrm{CDCl}_{3}, 500 \mathrm{MHz}\right): \delta=8.57$ (s, 1H, triazole), $7.91(\mathrm{~d}, J=12.3 \mathrm{~Hz}, 1 \mathrm{H}, \mathrm{CH}), 7.60$ (s, 1H, H4), 7.52-7.51 (m, 3H, H5, H3', H5'), 7.17 (d, $\left.J=8.4 \mathrm{~Hz}, 2 \mathrm{H}, \mathrm{H} 2^{\prime}, \mathrm{H6}^{\prime}\right), 6.93-6.91$ (m, 2H, H6, H8), 6.34 $(\mathrm{d}, J=12.3 \mathrm{~Hz}, 1 \mathrm{H}, \mathrm{CH}), 5.51\left(\mathrm{~s}, 2 \mathrm{H}, \mathrm{CH}_{2}\right), 5.22(\mathrm{~s}, 2 \mathrm{H}$, $\left.\mathrm{CH}_{2}\right), 3.17\left(\mathrm{~s}, 3 \mathrm{H}, \mathrm{CH}_{3}\right), 2.96\left(\mathrm{~s}, 3 \mathrm{H}, \mathrm{CH}_{3}\right) \mathrm{ppm} .{ }^{13} \mathrm{C} \mathrm{NMR}$ $\left(\mathrm{CDCl}_{3}, 125 \mathrm{MHz}\right): \delta=182.4,162.9,160.1,156.6,154.9$, $146.6,144.4,143.5,133.3,132.4,130.7,129.8,123.3$, 123.1, 122.9, 112.7, 100.8, 95.2, 62.4, 53.6, 45.2, 37.6 ppm. Anal. calcd. for $\mathrm{C}_{24} \mathrm{H}_{21} \mathrm{BrN}_{4} \mathrm{O}_{4}$ : C, 56.59; $\mathrm{H}, 4.16 ; \mathrm{N}, 11.00$. Found: C, 56.68; H, 4.38; N, 10.87 (Additional file 1).

\section{Inhibitory activities against $\mathrm{AChE}$ and BuChE}

All enzymes and reagents required for the assay were obtained from Aldrich. The in vitro anticholinesterase activity of all synthesized compounds $10 \mathbf{a}-\mathbf{m}$ was assayed using modified Ellman's method using a 96-well plate reader (BioTek ELx808) according to the literature $[36,42]$. Initially, the stock solutions of compounds $\mathbf{1 0}$ were prepared by dissolving the test compound (1 mg) in DMSO $(1 \mathrm{~mL})$ and then, diluted solutions at final concentrations of $1,10,20$, and $40 \mu \mathrm{g} / \mathrm{mL}$ were prepared 
using methanol. Each well contained $50 \mu \mathrm{L}$ potassium phosphate buffer $\left(\mathrm{KH}_{2} \mathrm{PO}_{4} / \mathrm{K}_{2} \mathrm{HPO}_{4}, 0.1 \mathrm{M}, \mathrm{pH} 8\right), 25$ $\mu \mathrm{L}$ sample solution, and $25 \mu \mathrm{L}$ enzyme (final concentration $0.22 \mathrm{U} / \mathrm{mL}$ in buffer). Control experiments were also performed under the same conditions without enzyme. After incubation at room temperature for $15 \mathrm{~min}, 125 \mu \mathrm{L}$ DTNB (3 $\mathrm{mM}$ in buffer) was added and the characterization of enzymatic reaction was spectrometrically performed at $405 \mathrm{~nm}$ followed by the addition of substrate (ATCI $3 \mathrm{mM}$ in water) after $5-10 \mathrm{~min}$. The $\mathrm{IC}_{50}$ values were determined graphically from inhibition curves (log inhibitor concentration vs. percent of inhibition). Also, the same method was used for the BuChE inhibition assay.

\section{Kinetic characterization of BuChE inhibitory activity}

The kinetic study for the inhibition of BuChE by compound 10h was carried out according to Ellman's method used for the inhibition assay using four different concentrations of inhibitor $(0,10.7,42.9$, and $85.8 \mu \mathrm{M})$. The Lineweaver-Burk reciprocal plot was provided by plotting $1 / \mathrm{V}$ against $1 /[\mathrm{S}]$ at variable concentrations of butyrylthiocholine as the substrate (187.5, 750, 1500, $3000 \mu \mathrm{M})$. The inhibition constant $K i$ was achieved by the plot of slopes versus the corresponding concentrations of compound 10h [43, 44].

\section{Inhibition of $A \beta_{1-42}$ aggregation and disaggregation of aggregated $A \beta_{1-40}$ induced by $A C h E$}

Inhibition of $A \beta 1-42$ self-aggregation was measured by ThT fluorescence assay. The details of the method were reported in our previous study [45]. To study $A \beta_{42}$ aggregation inhibition, a reported method, based on the fluorescence emission of ThT was followed. Briefly, the mixtures of $A \beta_{1-40}$ peptide (Bachem company, Switzerland) and AChE (Sigma, Electrophorus electricus), in the presence or absence of the test inhibitor were incubated for $24 \mathrm{~h}$ at room temperature. The final concentrations of $\mathrm{A} \beta$ (dissolved in DMSO and diluted $0.215 \mathrm{M}$ sodium phosphate buffer, $\mathrm{pH} 8$ ), AChE (dissolved in $0.215 \mathrm{M}$ sodium phosphate buffer, $\mathrm{pH} 8.0$ ), and the test compound are $200 \mu \mathrm{M}, 2 \mu \mathrm{M}$ and $100 \mu \mathrm{M}$, respectively. After co-incubation, $20 \mu \mathrm{L}$ of the mixed solution was diluted to a final volume of $2 \mathrm{~mL}$ with $\mathrm{ThT}(1.5 \mu \mathrm{M}$ in $50 \mathrm{mM}$ glycine- $\mathrm{NaOH}$ buffer, $\mathrm{pH}$ 8.5) and the absorbance was measured with a multi-mode plate reader at the excitation and emission wavelength of $\lambda \mathrm{ex}=450 \mathrm{~nm}$ and $\lambda \mathrm{em}=485 \mathrm{~nm}$, respectively [45].

\section{Neuroprotection assay against $A \beta$-induced damage}

MTT reduction assay was used to evaluate the neuroprotective effect of compound $\mathbf{1 0 h}$ on neuronal PC12 cell damage induced by $A \beta_{25-35}$. The cells were grown in monolayer culture on collagen-coated plates at $37{ }^{\circ} \mathrm{C}$ in a humidified atmosphere of $5 \% \mathrm{CO}_{2}$. Neuronal PC12 cells were plated at a density of $5 \times 10^{5}$ cells/well on 96-well plates. The cells were pre-incubated with compound 10h for $3 \mathrm{~h}$ before human $\mathrm{A} \beta_{25-35}$ (final concentration of $5 \mu \mathrm{M})$ was added. After $24 \mathrm{~h}, 90 \mu \mathrm{L}$ the medium was taken out and $20 \mu \mathrm{L}$ of MTT $(0.5 \mathrm{mg} /$ $\mathrm{ml}$ dissolved in RPMI containing phenol red) was added and incubated for an additional $2 \mathrm{~h}$ at $37^{\circ} \mathrm{C}$. The absorbance (A570 nm) was measured using a Bio-Rad microplate reader (Model 680, Bio-Rad). The details were reported in our previous work $[33,46]$.

\section{Metal chelation studies}

To study the metal chelating ability, the solutions of compound $10 \mathrm{~h}$ and $\mathrm{Fe}^{2+}, \mathrm{Cu}^{2+}$, and $\mathrm{Zn}^{2+}$ ions (from $\mathrm{FeSO}_{4}, \mathrm{CuCl}_{2} \cdot 2 \mathrm{H}_{2} \mathrm{O}$, and $\mathrm{ZnCl}_{2}$ ) were prepared in methanol. The mixture of compound $\mathbf{1 0 h}(1 \mathrm{~mL})$ and the test ion solutions $(1 \mathrm{~mL})$ with the same final concentration of $20 \mu \mathrm{M}$ in a $1 \mathrm{~cm}$ quartz cuvette was incubated at room temperature for $30 \mathrm{~min}$. Then, the absorption spectra were recorded in the range of 200-600 nm.

The stoichiometry of complex $\mathbf{1 0 h}-\mathrm{Cu}^{2+}$ was also studied using the molar ratio method [47, 48]. The concentration of compound $\mathbf{1 0 h}$ was $20 \mu \mathrm{M}$ and the final concentration of $\mathrm{Cu}^{2+}$ ranged from $0-44 \mu \mathrm{M}$ with $4 \mu \mathrm{M}$ intervals at $303.5 \mathrm{~nm}$. The plot was obtained by the corresponding absorption versus mole fraction of $\mathrm{Cu}^{2+}$ to ligand 10h. All experiments were performed in triplicate.

\section{Molecular docking}

The molecular docking studies of the most potential ligand was performed on BuChE (PDB code: 4BDS) [39] to observe the binding orientation and consensual binding interactions using AutoDock 4.2. The X-ray crystal structure of the receptor was downloaded from the PDB database. All water and ligand molecules were removed from the structure, and the protein was prepared for docking. The co-crystallized ligand within the PDB structures was defined as a center of the binding site. All ligands were created using Chem3D Ultra software, and energy minimizations were done by the semiempirical $\mathrm{MM}^{+}$[49]. The compounds were docked into the active site of proteins using default parameters for each ligand with 100 runs and 27,000 as the maximum number of generations. The grid boxes were set with 60,60, and 60 points in the $\mathrm{x}, \mathrm{y}$, and $\mathrm{z}$ directions, respectively. All other options were set as default. The calculated geometries were ranked in terms of free energy of binding and the best pose was selected for further analysis. Molecular 
visualizations were performed by Discovery Studio 4.0 client software [20].

\section{Prediction of ADME descriptors}

ADME-Tox properties of the synthesized compounds were performed by using online servers especially https ://lmmd.ecust.edu.cn:8000/predict/ and https://pread met.bmdrc.kr.

\section{Conclusion}

In summary, a new series of 1,2,3-triazole-dimethylaminoacryloyl-chromenone derivatives were designed and synthesized as multifunctional anti-Alzheimer's agents. All the target compounds were synthesized and screened as AChE/BuChE inhibitors. The most active compound was further evaluated by the multiple biological activities including $A \beta_{1-42}$ aggregation inhibition, metal-chelating properties, and neuroprotective effects against $\mathrm{A} \beta_{25-35}$-induced PC12 cell injury. Our results showed that these compounds had a high inhibitory potency and selectivity towards BuChE with an $\mathrm{IC}_{50}$ value of $21.71 \mu \mathrm{M}$ for $10 \mathrm{~h}$ as the most potent BuChE inhibitor. The inhibition kinetic analysis revealed a mixed-type inhibition pattern for this compound. The molecular modeling study of the most potent compound $10 \mathrm{~h}$ with $\mathrm{BuChE}$ indicated that it bound to both CAS and PAS of the BuChE. Moreover, this compound had a significant anti-A $\beta$ aggregation capacity and served as a metal chelator. These results indicated that this hybridization approach could be a successful strategy for the further developments of potential multifunctional candidates against AD.

\section{Supplementary information}

Supplementary information accompanies this paper at https://doi. org/10.1186/s13065-020-00715-0.

Additional file 1. The supplementary file include copies of NMR spectra and elemental analysis report.

\section{Abbreviations \\ AD: Alzheimer's disease; AChE: Acetylcholinesterase; BuChE: Butylcholinest- erase; CAS: Catalytic active site; PAS: Peripheral anionic site; Aß: Amyloid $\beta$ eta; APP: Amyloid precursor protein; BACE1: $\beta$-Site APP cleaving enzyme-1; NFTs: Neurofibrillary tangles; $\mathrm{IC}_{50}$. The half maximal inhibitory concentration; ${ }^{1} \mathrm{H}$ NMR: Proton nuclear magnetic resonance; ${ }^{13} \mathrm{C}$ NMR: Carbon-13 nuclear magnetic resonance.}

\section{Acknowledgments}

The authrs acknowledged the support from Tehran University of Medical Sciences and National Institute for Medical Research Development.

This paper is dedicated to the memory of our unique teacher in Chemistry and Medicinal Chemistry, Professor Abbas Shafiee (1937-2016)

\section{Authors' contributions}

MS contributed to the design and characterization of compounds as well as preparation of the manuscript. HKA synthesized compounds. Al performed docking study and contributed to the preparation of the manuscript. AR performed the biological assay. SNAB and OF supervised the biological tests. TA supervised all phases of the study. All authors read and approved the final manuscript.

\section{Funding}

This work was supported by grants from National Institute for Medical Research Development with project No. 958756.

\section{Availability of data and materials}

The datasets used and analyzed during the current study are available from the corresponding author on reasonable request.

\section{Ethics approval and consent to participate}

The manuscript does not contain studies with animal subjects.

\section{Consent for publication}

Not applicable.

\section{Competing interests}

The authors declare that they have no competing interests.

\section{Author details}

${ }^{1}$ Department of Medicinal Chemistry, Faculty of Pharmacy, Tehran University of Medical Sciences, Tehran, Iran. ${ }^{2}$ Medicinal and Natural Products Chemistry Research Center, Shiraz University of Medical Sciences, Shiraz, Iran. ${ }^{3}$ Persian Medicine and Pharmacy Research Center, Tehran University of Medical Sciences, Tehran, Iran. ${ }^{4}$ Department of Pharmaceutical Chemistry, College of Pharmacy, Aljouf University, Sakaka 2014, Aljouf, Saudi Arabia. ${ }^{5}$ Medicinal Plants Research Center, Faculty of Pharmacy, Tehran University of Medical Sciences, Tehran, Iran.

Received: 8 July 2020 Accepted: 8 October 2020

Published online: 27 October 2020

\section{References}

1. Maramai S, Benchekroun M, Gabr MT, Yahiaoui S (2020) Multitarget therapeutic strategies for Alzheimer's disease: Review on emerging target combinations. BioMed Res Int 2020:5120230

2. Iraji A, Khoshneviszadeh M, Firuzi O, Khoshneviszadeh M, Edraki N (2020) Novel small molecule therapeutic agents for Alzheimer disease: focusing on BACE1 and multi-target directed ligands. Bioorg Chem 97:103649

3. Najafi Z, Mahdavi M, Saeedi M, Karimpour-Razkenari E, Asatouri R, Vafadarnejad F, Moghadam FH, Khanavi M, Sharifzadeh M, Akbarzadeh T (2017) Novel tacrine-1,2,3-triazole hybrids: in vitro, in vivo biological evaluation and docking study of cholinesterase inhibitors. Eur J Med Chem 125:1200-1212

4. Rahman A (2018) Frontiers in clinical drug research-CNS and neurological disorders. Bentham Science Publishers, Sharjah

5. Li Q, Yang H, Chen Y, Sun H (2017) Recent progress in the identification of selective butyrylcholinesterase inhibitors for Alzheimer's disease. Eur J Med Chem 132:294-309

6. Vafadarnejad F, Karimpour-Razkenari E, Sameem B, Saeedi M, Firuzi O, Edraki N, Mahdavi M, Akbarzadeh T (2019) Novel N-benzylpyridinium moiety linked to arylisoxazole derivatives as selective butyrylcholinesterase inhibitors: synthesis, biological evaluation, and docking study. Bioorg Chem 92:103192

7. Campanari M-L, Navarrete F, Ginsberg SD, Manzanares J, Sáez-Valero J (2016) García-Ayllón M-S (2016) Increased expression of readthrough acetylcholinesterase variants in the brains of Alzheimer's disease patients. J Alzheimers Dis 53(3):831-841

8. Darvesh S, Hopkins DA, Geula C (2003) Neurobiology of butyrylcholinesterase. Nat Rev Neurosci 4(2):131

9. Maurice T, Strehaiano M, Siméon N, Bertrand C, Chatonnet A (2016) Learning performances and vulnerability to amyloid toxicity in the butyrylcholinesterase knockout mouse. Behav Brain Res 296:351-360 
10. Dolles D, Hoffmann M, Gunesch S, Marinelli O, Möller J, Santoni G, Chatonnet A, Lohse MJ, Wittmann H-J, Strasser A (2018) Structure-activity relationships and computational investigations into the development of potent and balanced dual-acting butyrylcholinesterase inhibitors and human cannabinoid receptor 2 ligands with pro-cognitive in vivo profiles. J Med Chem 61(4):1646-1663

11. Greig NH, Utsuki T, Ingram DK, Wang Y, Pepeu G, Scali C, Yu Q-S, Mamczarz J, Holloway HW, Giordano T (2005) Selective butyrylcholinesterase inhibition elevates brain acetylcholine, augments learning and lowers Alzheimer $\beta$-amyloid peptide in rodent. Proc Natl Acad Sc 102(47):17213-17218

12. Soreq H: Human cholinesterases and anticholinesterases: Academic Press; 2012.

13. Lane RM, Potkin SG, Enz A (2006) Targeting acetylcholinesterase and butyrylcholinesterase in dementia. Int I Neuropsychopharmacol 9(1):101-124

14. Nicolet Y, Lockridge O, Masson P, Fontecilla-Camps JC, Nachon F (2003) Crystal structure of human butyrylcholinesterase and of its complexes with substrate and products. J Biol Chem 278(42):41141-41147

15. Tripathi MK, Sharma P, Tripathi A, Tripathi PN, Srivastava P, Seth A, Shrivastava SK (2020) Computational exploration and experimental validation to identify a dual inhibitor of cholinesterase and amyloid-beta for the treatment of Alzheimer's disease. J Comput Aided Mol Des 34(9):983-1002

16. Sharma P, Srivastava P, Seth A, Tripathi PN, Banerjee AG, Shrivastava SK (2019) Comprehensive review of mechanisms of pathogenesis involved in Alzheimer's disease and potential therapeutic strategies. Prog Neurobiol 174:53-89

17. Cherny RA, Atwood CS, Xilinas ME, Gray DN, Jones WD, McLean CA, Barnham KJ, Volitakis I, Fraser FW, Kim Y-S (2001) Treatment with a copperzinc chelator markedly and rapidly inhibits $\beta$-amyloid accumulation in Alzheimer's disease transgenic mice. Neuron 30(3):665-676

18. Zatta P, Drago D, Bolognin S, Sensi SL (2009) Alzheimer's disease, metal ions and metal homeostatic therapy. Trends Pharmacol Sci 30(7):346-355

19. Andrisano V, Naldi M, De Simone A, Bartolini M (2018) A patent review of butyrylcholinesterase inhibitors and reactivators 2010-2017. Expert Opin Ther Pat 28(6):455-465

20. Vafadarnejad F, Mahdavi M, Karimpour-Razkenari E, Edraki N, Sameem B, Khanavi M, Saeedi M, Akbarzadeh T (2018) Design and synthesis of novel coumarin-pyridinium hybrids: In vitro cholinesterase inhibitory activity. Bioorg Chem 77:311-319

21. Saeedi M, Safavi M, Karimpour-Razkenari E, Mahdavi M, Edraki N, Moghadam FH, Khanavi M, Akbarzadeh T (2017) Synthesis of novel chromenones linked to 1,2,3-triazole ring system: investigation of biological activities against Alzheimer's disease. Bioorg Chem 70:86-93

22. Yazdani M, Edraki N, Badri R, Khoshneviszadeh M, Iraji A, Firuzi O (2020) 5,6-Diphenyl triazine-thio methyl triazole hybrid as a new Alzheimer's disease modifying agents. Mol Divers 24:641-654

23. Moradi A, Faraji L, Nadri H, Hasanpour Z, Moghadam FH, Pakseresht B, Golshani M, Moghimi S, Ramazani A, Firoozpour L et al (2018) Synthesis, docking study, and biological evaluation of novel umbellipherone/ hymecromone derivatives as acetylcholinesterase/butyrylcholinesterase inhibitors. Med Chem Res 27(7):1741-1747

24. Fang J, Li Y, Liu R, Pang X, Li C, Yang R, He Y, Lian W, Liu A-L, Du G-H (2015) Discovery of multitarget-directed ligands against Alzheimer's disease through systematic prediction of chemical-protein interactions. J Chem Inf Model 55(1):149-164

25. Jiang Z, You Q, Zhang X (2019) Medicinal chemistry of metal chelating fragments in metalloenzyme active sites: a perspective. Eur J Med Chem 165:172-197

26. Kostova I, Bhatia S, Grigorov P, Balkansky S, Parmar VS, Prasad AK, Saso L (2011) Coumarins as antioxidants. Curr Med Chem 18(25):3929-3951

27. Tao D, Wang Y, Bao X-Q, Yang B-B, Gao F, Wang L, Zhang D, Li L (2019) Discovery of coumarin Mannich base derivatives as multifunctional agents against monoamine oxidase B and neuroinflammation for the treatment of Parkinson's disease. Eur J Med Chem 173:203-212

28. Najafi Z, Mahdavi M, Saeedi M, Karimpour-Razkenari E, Edraki N, Sharifzadeh M, Khanavi M, Akbarzadeh T (2019) Novel tacrine-coumarin hybrids linked to 1,2,3-triazole as anti-Alzheimer's compounds: In vitro and in vivo biological evaluation and docking study. Bioorg Chem 83:303-316

29. Jalili-Baleh L, Nadri H, Forootanfar H, Samzadeh-Kermani A, Küçükkılınç TT, Ayazgok B, Rahimifard M, Baeeri M, Doostmohammadi M, Firoozpour
L et al (2018) Novel 3-phenylcoumarin-lipoic acid conjugates as multifunctional agents for potential treatment of Alzheimer's disease. Bioorg Chem 79:223-234

30. Jiang N, Huang Q, Liu J, Liang N, Li Q, Li Q, Xie S-S (2018) Design, synthesis and biological evaluation of new coumarin-dithiocarbamate hybrids as multifunctional agents for the treatment of Alzheimer's disease. Eur J Med Chem 146:287-298

31. Jalili-Baleh L, Forootanfar H, Küçükkılınç TT, Nadri H, Abdolahi Z, Ameri A, Jafari M, Ayazgok B, Baeeri M, Rahimifard M et al (2018) Design, synthesis and evaluation of novel multi-target-directed ligands for treatment of Alzheimer's disease based on coumarin and lipoic acid scaffolds. Eur J Med Chem 152:600-614

32. Sang Z, Wang K, Shi J, Liu W, Cheng X, Zhu G, Wang Y, Zhao Y, Qiao Z, Wu A et al (2020) The development of advanced structural framework as multi-target-directed ligands for the treatment of Alzheimer's disease. Eur Med Chem 192:112180

33. Iraji A, Firuzi O, Khoshneviszadeh M, Tavakkoli M, Mahdavi M, Nadri H, Edraki N, Miri R (2017) Multifunctional iminochromene-2H-carboxamide derivatives containing different aminomethylene triazole with BACE1 inhibitory, neuroprotective and metal chelating properties targeting Alzheimer's disease. Eur J Med Chem 141:690-702

34. Jiang Y, Liu G, Wang X, Hu J, Zhang G, Liu S (2015) Cytosol-specific fluorogenic reactions for visualizing intracellular disintegration of responsive polymeric nanocarriers and triggered drug release. Macromolecules 48(3):764-774

35. Lewis WG, Green LG, Grynszpan F, Radić Z, Carlier PR, Taylor P, Finn M, Sharpless KB (2002) Click chemistry in situ: acetylcholinesterase as a reaction vessel for the selective assembly of a femtomolar inhibitor from an array of building blocks. Angew Chem Int Ed 41(6):1053-1057

36. Ellman GL, Courtney KD, Andres V Jr, Featherstone RM (1961) A new and rapid colorimetric determination of acetylcholinesterase activity. Biochem Pharmacol 7(2):88-95

37. Roldán-Peña JM, Romero-Real V, Hicke J, Maya I, Franconetti A, Lagunes I, Padrón JM, Petralla S, Poeta E, Naldi M et al (2019) Tacrine-O-protected phenolics heterodimers as multitarget-directed ligands against Alzheimer's disease: Selective subnanomolar BuChE inhibitors. Eur J Med chem 181:111550

38. Drew SC (2017) The case for abandoning therapeutic chelation of copper ions in Alzheimer's Disease. Front Neurosci 11:317

39. Nachon F, Carletti E, Ronco C, Trovaslet M, Nicolet Y, Jean L, Renard P-Y (2013) Crystal structures of human cholinesterases in complex with huprine $W$ and tacrine: elements of specificity for anti-Alzheimer's drugs targeting acetyl-and butyryl-cholinesterase. Biochem J 453(3):393-399

40. Chandrasekaran B, Abed SN, Al-Attraqchi O, Kuche K, Tekade RK. Chapter 21-Computer-Aided Prediction of Pharmacokinetic (ADMET) Properties. In: Dosage Form Design Parameters. edn. Edited by Tekade RK: Academic Press; 2018. p. 731-755.

41. Liu G, Shi G, Sheng H, Jiang Y, Liang H, Liu S (2017) Doubly caged linker for and-type fluorogenic construction of protein/antibody bioconjugates and in situ quantification. Angew Chem 129(30):8812-8817

42. Rastegari A, Nadri H, Mahdavi M, Moradi A, Mirfazli SS, Edraki N, Moghadam FH, Larijani B, Akbarzadeh T, Saeedi M (2019) Design, synthesis and anti-Alzheimer's activity of novel 1, 2, 3-triazole-chromenone carboxamide derivatives. Bioorg Chem 83:391-401

43. Saeedi M, Mohtadi-Haghighi D, Mirfazli SS, Mahdavi M, Hariri R, Lotfian H, Edraki N, Iraji A, Firuzi O, Akbarzadeh T (2019) Design and synthesis of selective acetylcholinesterase inhibitors: arylisoxazole-phenylpiperazine derivatives. Chem Biodivers 16(2):e1800433

44. Mahdavi M, Hariri R, Mirfazli SS, Lotfian H, Rastergari A, Firuzi O, Edraki N, Larijani B, Akbarzadeh T, Saeedi M (2019) Synthesis and biological activity of some benzochromenoquinolinones: tacrine analogs as potent antiAlzheimer's agents. Chem Biodivers 16(4):e1800488

45. Jalili-Baleh L, Nadri H, Moradi A, Bukhari SNA, Shakibaie M, Jafari M, Golshani M, Homayouni Moghadam F, Firoozpour L, Asadipour A et al (2017) New racemic annulated pyrazolo[1,2-b]phthalazines as tacrine-like AChE inhibitors with potential use in Alzheimer's disease. Eur J Med Chem 139:280-289

46. Yazdani $\mathrm{M}$, Edraki N, Badri R, Khoshneviszadeh M, Iraji A, Firuzi O (2019) Multi-target inhibitors against Alzheimer disease derived from 3-hydrazinyl 1,2,4-triazine scaffold containing pendant phenoxy 
methyl-1,2,3-triazole: design, synthesis and biological evaluation. Bioorg Chem 84:363-371

47. Iraji A, Firuzi O, Khoshneviszadeh M, Nadri H, Edraki N, Miri R (2018) Synthesis and structure-activity relationship study of multi-target triazine derivatives as innovative candidates for treatment of Alzheimer's disease. Bioorg Chem 77:223-235

48. Karamać M (2009) Chelation of CU (II), Zn (II), and Fe (II) by tannin constituents of selected edible nuts. Int J Mol Sci 10(12):5485-5497

49. Iraji A, Adelpour T, Edraki N, Khoshneviszadeh M, Miri R, Khoshneviszadeh M (2020) Synthesis, biological evaluation and molecular docking analysis of vaniline-benzylidenehydrazine hybrids as potent tyrosinase inhibitors. BMC Chem 14(1):28

\section{Publisher's Note}

Springer Nature remains neutral with regard to jurisdictional claims in published maps and institutional affiliations.
Ready to submit your research? Choose BMC and benefit from:

- fast, convenient online submission

- thorough peer review by experienced researchers in your field

- rapid publication on acceptance

- support for research data, including large and complex data types

- gold Open Access which fosters wider collaboration and increased citations

- maximum visibility for your research: over $100 \mathrm{M}$ website views per year

At BMC, research is always in progress.

Learn more biomedcentral.com/submissions 